\title{
COMMENTARY ON THE PAPERS PRESENTED AT THE NINTH ANNUAL OIL AND GAS LAW SEMINAR
}

\author{
CHARLES J. MEYERS*
}

\begin{abstract}
The Canadian Petroleum Law Foundation was very fortunate in having Professor Charles J. Meyers as Seminar Commentator at its Ninth Annual Research Seminar in Oil and Gas Law. Professor Meyers is a distinguished oil and gas law teacher, is the author of numerous articles on oil and gas law and is the co-author of Williams and Meyers, Oil and Gas Law. Professor Meyers was gracious enough to commit the following of his comments at the seminar to writing.
\end{abstract}

\section{A. INTRODUCTION}

The scholarly papers that follow were presented at the Ninth Annual Seminar of the Canadian Petroleum Law Foundation in Jasper, Alberta, on June 11th, 12th, and 13th, 1970. I had the honor to serve as commentator from the United States at the meeting, with the responsibility of providing an American perspective on the Canadian problems discussed in the papers. What follows is a distillation of comments I made at the Seminar sessions.

\section{B. REGULATION OF NATURAL GAS SALES}

Perhaps the most controversial issue facing the Canadian petroleum industry today is regulation of the price of natural gas. The institutional setting in Canada for a decision of this issue is somewhat different from what it was in the United States sixteen years ago. In my country the responsibility was not sought but was thrust on the regulatory agency, the Federal Power Commission. In the Phillips Petroleum case, ${ }^{1}$ decided by the Supreme Court of the United States in 1954, it was held that the Natural Gas Act ${ }^{2}$ required the regulation of price at the wellhead for gas sold for resale in interstate commerce. The Commission had resisted jurisdiction over such sales, and it entered into rate regulation only after being required to do so by the High Court. In contrast, as the paper prepared by Messrs. Gibbs, Knowles, and McFarlane ${ }^{3}$ shows, the National Energy Board itself initiated a hearing on a broad range of policy matters relating to the effect on the domestic market of the export of gas to the United States at both regulated and unregulated prices. There would seem to be little doubt of the jurisdiction of the National Energy Board, unlike the situation in the United States prior to 1954 when Federal Power Commission jurisdiction was bitterly contested. Certainly with respect to the precise question before the Board at the hearing conducted from November, 1969, through March, 1970, Section 83 of the Act is clear: In acting upon applications for licenses to export gas, the Board may consider whatever appears to be relevant and in addition must satisfy itself that (1) an adequate supply is left for reasonably foreseeable Canadian requirements and (2) the price to be charged by the applicant is "just and reasonable in relation to the public interest."

- B.A. (Rice), LLB. (Texas), LL.M., J.S.D. (Columbia). Professor of Law, Stanford University.

1 Phillips Petroleum Co. v. Wisconsin, 347 U.S. 672 (1954).

215 U.S.C. $\$ 8$ 717.717w (1964), (originally enacted as Act of June 21.1938, ch. 556, 52 Stat. 821).

${ }^{3}$ Gibbs, Knowles and MacFarlane, A Review of the National Energy Board Policies and Practice and Recent Hearings, infra, at 523 
It may be worth noting in passing that the standards governing agency action in Canada are as vague as those set forth for the guidance of the Federal Power Commission. The Canadian formula with respect to prices is "just and reasonable in relation to the public interest"; the Natural Gas Act uses the same formula ("just and reasonable"), and both the Canadian and American statutes speak of "the public convenience and necessity" with respect to licensing pipeline construction. Scholars and practitioners in the United States have long been distrubed by the vagueness of these standards. They seem to confide almost unlimited discretion to the administrative agency; they make it possible for the agency to hide the basis of its decision; and in the United States under the substantial evidence rule they provide very little basis for judicial review. This vagueness allows agencies to engage in improper practices, ranging from honest but highly idiosyncratic actions to outright corruption. Too often the consequence is loss of public confidence in the integrity of the decision-making process. Certainly one theme that runs through Anglo-American legal history is the utility of stare decisis as a limitation on judicial power, for it reduces the scope for judicial corruption and judicial autocracy. It is fair to say, I think, that the judiciary in the United States enjoys a higher reputation than do administrative agencies, owing in part, as I believe, to the fact that judges have imposed upon themselves meaningful norms for the decision of legal controversies. The specification of more precise standards would, I think, help administrative agencies reach better decisions which would be more readily accepted by the public because satisfactory reasons could be given for them.

The hearing concluded in March, 1970, may mark the National Energy Board's first step down the long and tortuous road that the FPC has followed for the last 16 years in the United States. After jurisdiction was thrust upon it, the FPC had the problem of deciding the rate base for natural gas companies subject to the Act. The traditional "cost of service" standard would not serve to fix the price of gas to the producer at the wellhead. Although the FPC started down this blind alley, it soon discovered that some other method of regulating rates would have to be adopted because by employing the traditional formula and tripling its staff it could not dispose of the cases before it in 1960 until the year 2043 A.D. ${ }^{4}$ It soon turned to a field-price system, employing its certification power under Section 7 of the Act to fix prices when gas sales contracts were approved. Concurrently, it sought authority to establish area rates on the basis of average costs, and this authority was confirmed in 1968 in the Permian Basin Area Rate Cases. ${ }^{5}$ Recognizing that incentives for further exploration for gas were necessary, the Commission in the Permian Basin case adopted a two-price system, fixing a higher price for gas committed to interstate commerce after January 1, 1961, which price contained an incentive ingredient not tied to average costs of service. Canadian observers should note that it took 14 years for this rate regulation system to receive final approval and become operative. Observers may also be interested to note that a staff report on natural gas supply and demand, released on October 1,1969, concludes that there is a need for imme-

' Phillips Petroleum Co., 24 F.P.C. 537, 546 (1969), cited in Permian Basin Area Rate Cases, 390 U.S. 747, 757.58, n. 13 (1968).

s Permian Basin Area Rate Cases, 390 U.S. 747 (1968). 
diate action by industry and government to reverse the declining natural gas supply in the United States. The report finds that the national reserves to production ratio will dip from a current level of 14.6 to a level of 10.2 by the end of 1973. The South Louisiana Area Rate Cases, ${ }^{6}$ recently decided by the Commission, seem to reflect this concern about dwindling supplies by providing even greater incentives through a three-level price structure.

Returning to the paper of Messrs. Gibbs, Knowles and MacFarlane, we can see that, at bedrock, there are two principal interest groups involved in the Canadian controversy: Western producers and royalty owners seek unregulated prices in an effort to maximize the value of the resource. Eastern consumer interests, represented by distributing companies and the provincial governments, desire to keep the price low (for the time being), by limiting the amount of gas that is exported to the United States, and by regulating the price of such gas so as to prevent the triggering of rate increases under escalation clauses and most-favored-nation clauses in gas purchase contracts. The position of eastern Canada seems to be that you may export, but only in the amount and: at prices that will save for the Eastern consumer an adequate supply of gas at reasonable prices. Challenging western Canada's right to maximize, the East asserts that the natural gas of the West is a national resource, not a regional one.

Stripped of the rhetoric, the issue of natural gas price regulation comes down to a choice between two bases of decision-making. The National Energy Board, and ultimately the Federal government, must decide whether price regulation will be based on economic criteria or on political and social criteria. If the choice is the former, the relevant question is, does price fixing promote the efficient allocation of the resource. A producer monopoly may well restrain the production of gas and thus deny society the use of the optimal amount. In this case, price regulation may be appropriate. If, however, competition does prevail among the producer-sellers of gas and between gas and other energy sources, it is doubtful that price regulation is necessary to prevent misallocation of the resource. In short, if economic efficiency is the criterion of price regulation and if the Dominion of Canada starts with the premise that in the absence of contrary proof the market is the most efficient allocator of resources, the burden of proof would seem to be on the eastern interests to show a market defect in order to justify government intervention.

But if, as I suspect, the statute and the nation contemplate that the allocation of natural gas will be made on criteria of political and social policy, then we should frankly concede that we are discussing a far different issue from economic efficiency and we should not be misled by irrelevant references to it. The eastern demand for an adequate supply of natural gas at reasonable prices is a political claim, not an economic proposition, and the political process of bargaining and compromise should be used to resolve it.

\section{POTASH PRORATIONING}

That economic efficiency is not always desired by producers is demonstrated by the adoption of the Saskatchewan Potash Proration-

6 Area Rate Proceeding (Southern Louisiana Area), 40 F.P.C. 530 (1968), appeal pending. United States Court of Appeals for the Fifth Circuit. 
ing regime, described by Mr. Ready. ${ }^{7}$ What is sauce for the goose in the East is not always sauce for the gander in the West. Here, in effect, the provincial government of Saskatchewan has sanctioned a producer combination to restrict production of potash in order to increase the price. While the statute is clothed in the traditional language of conservation and protection of correlative rights, it cannot be claimed that potash production is affected by the "common pool" problem inherent in oil and gas reservoirs. .Under certain circumstances, an argument based on economic efficiency can be made for restricting production of common-pool resources such as oil, gas and ground water. Even here, however, unitization may be a better solution than production quotas. ${ }^{8}$ But potash is not a common-pool resource, and there seems to be very little difference between mining potash, mining coal or any other hard mineral or cutting timber. The policy justification, then, for the prorationing regime must lie in social and.political policy, which introduces considerations not too different from those discussed in connection with the regulation of natural gas wellhead prices.

\section{RIGHTS OF LESSOR IN PREPAYMENTS}

While it may be true that the most important problems of natural resource management arise over the criteria for allocating the resources-as in the case of natural gas and potash-this is not to deny that difficult legal questions arise in connection with the marketing of the resources. There is ample historical precedent for the proposition that political decisions can generate highly technical doctrines of law. One need cite only the Statute of Uses, which embodied a political and fiscal decision of Henry VIII but produced the Rule Against Perpetuities which plagues some of us to this day.

Two papers presented at the Seminar deal with the complexities of marketing natural gas. Mr. Holland's paper makes a comparative analysis of gas purchase contracts 9 and Mr. Muir's paper deals with split sales of gas. ${ }^{10}$ Both papers discuss a contract provision not familiar in the United States, the prepayment clause. While taking a variety of forms, this clause in essence provides that a sum of money will be deposited with the seller of gas to be recovered by the purchaser out of later production. Such a provision raises a question of the duty owed by the lessee-producer-seller to the royalty owner. Does the royalty owner have any claims against the prepayment? One agrument supporting the negative seems to run as follows: Where the lease is being kept in force under a shut-in gas royalty clause ${ }^{11}$ then royalty is being paid, and the prepayment sum represents something other than royalty. The argument then proceeds by citing the production royalty clause which requires the payment of royalty for "gas produced from the said lands and marketed or used off the said lands."12 The argument concludes: Since the lease is in force under the shut-in royalty clause and since royalty is being paid under both that clause and the production royalty clause, further payment is not necessary.

; Ready, The Saskatchewan Potash Prorationing Scheme, infra, at 592.

* E. Rostow, A National Policy for the Oil Industry (1948).

9 Holland, Comparative Analysis of Gas Purchase Contracts, infra, at 479.

10 Muir, Split Sales of Gas, infra, at 496.

"Such clauses provide that while shut in payments are being made "it shall be considered under all provisions of this lease that leased substances are being produced from the said lands during the entire period for which such royalty is paid or tendered." Muir, supra, n. 10 at 517.

12 Muir, supra. n. 10 at 516. (Emphasis added). 
under the production royalty clause because no gas is being produced from the said lands nor is gas being marketed or used off the said lands.

However, it is thought that the presence in the lease of the shutin gas royalty clause and the payment of royalties thereunder do not negate or qualify the implied duty to use due diligence in the marketing of the product. ${ }^{13}$ This implied duty imposes upon the lessee the obligation to act as an ordinary prudent operator would act, giving due consideration to the interests of both lessee and lessor. In addition, duties of fair dealing and even of fiduciary responsibility are imposed upon the operator-manager in other areas where the ownership of interests in oil and gas are divided, and where one party has exclusive operating and management rights. ${ }^{14}$ As Mr. Muir notes "[T]he rewarding areas of implied contract, constructive trust, unjust enrichment and fiduciary relationship would [perhaps] provide a royalty owner with some kind of claim."15 Whatever legal doctrine may ultimately be selected to provide a remedy in this situation, this commentator anticipates that a remedy will be afforded the royalty owner, at least to the extent of the interest earned on his portion of the prepayment sum. And it would not be surprising for a court to take the remedy a step further and award the lessor his share of the prepayment fund, holding that the royalty owner, not his lessee, is entitled to determine how his capital shall be invested.

\section{E. RATABLE TAKE OF GAS}

Another problem to which Mr. Muir directs attention is that of nonratable take by purchasers from the several wells of the field. Experience from the United States demonstrates how complicated this problem can be when the national government regulates price but leaves to the states the protection of correlative rights. In Northern Natural Gas v. State Corp. Commission ${ }^{16}$ the gas pipeline purchaser was taking more gas from one portion of the field than from another, causing substantial drainage from the latter. When the Kansas Corporation Commission attempted to correct the situation by means of ratabletake orders, the Supreme Court struck down the order on the grounds that it conflicted with the exclusive jurisdiction of the Federal Power Commission to regulate wellhead prices. Having commented on the opinion elsewhere, ${ }^{17}$ I mention it here only to point out to Canadian readers the far-reaching and often unexpected consequences that obtain from national regulation of wellhead gas sales.

\section{F. SPECIAL LIMITATIONS IN LEASES}

An oil and gas lawyer from South of the Border finds himself on familiar ground with Mr. Currie's review of recent cases. ${ }^{18}$ Here we

3.1 Williams and Meyers. 5 Oil and Gas Law $\$ 858.2$ (1969). For a general discussion of the duty to use due diligence to market the product, see $\$ \$ 8: 33-858.3$.

14 Federal Land Bank of Houston v. United States, 168 F. Supp. 788, 10 O. \& G.R. 311 (Ct. Cl. 1958), duty of "utmost fair dealing and diligence" owed by executive to non-participating royalty owner; Rees v. Briscoe, 315 P. 2d 758, 7 O. \& G.R. 1452 (Okla. 1957), constructive trust imposed to preserve an overriding royalty interest where assignee of an oil and gas lease violated a confidential relationship in letting the first lease expire and taking a second lease claimed to be free of the overriding royalty interest created under the first lease.

1.. Muir, supra, n. 10 at 517.

16372 U.S. 84 (1963).

17 Meyers, Federal Preemption and State Conservation in Northern Natural Gas, (1964) 77 Harv. L. Rev. 689.

in Currie, Recent Cases and Developments in (Bil and (ias Lau, infra, at 452. 
encounter once more the problems of termination of oil and gas leases through failure to secure production by the end of the primary term, through misadventure in the tender of delay rentals, and for other causes arising from the failure to satisfy the special limitations of the oil and gas lease. The American observer notes the strenuous efforts by counsel for lessees to avoid termination through the doctrine (or various doctrines) of estoppel. It would appear that in Canada these arguments have no greater success than they have had in the United States, where only a handful of cases adopt the doctrine to prevent termination of the lease. ${ }^{19}$ The standard position seems to be that an oil and gas lease creates a determinable property interest, whether that interest be a fee estate or a profit $\grave{a}$ prendre; when the limiting event of the special limitation occurs, the interest terminates automatically. Thus in the famous example of a fee simple determinable, "to A and his heirs so long as St. Paul's Church shall stand," when St. Paul's Church falls down the estate terminates, and the court can no more put the estate back together again than it can the church.

In retrospect, it seems unfortunate that oil and gas operators adopted the fee simple determinable-special limitation model in writing oil and gas leases, employing such clauses as a primary term "for five years and so long thereafter as oil or gas is produced," the unless rental clause, and the various drilling operations clauses. A long line of unfortunate decisions, many of them from Texas, demonstrates the unwarranted hardship on the lessee of the special limitation structure. ${ }^{20}$ The result in Texas is not only hardship on the particular lessee, who loses his lease despite substantial compliance with the purposes of the lease, but also hardship on the industry at large. The harshness of a particular result often leads the court to avoid the result in a later case by focusing on minute variations in lease language. ${ }^{21}$ The consequence for the industry at large is a very low level of predictability.

One wonders if it is too late for the industry to change its forms. There has already been some movement to a drill-or-pay clause, which requires notice before forfeiture for nonpayment of rentals can be effected. But perhaps a further step can be taken. Perhaps the agreement between the lessor and the lessee can take a purely contractual form, in which the lessee promises to drill and seek production within five years (or some other appropriate primary term) or to surrender the lease. The lessee further promises in the meantime to pay a sum of money for the right to delay drilling until the end of the primary term, but he has the right to surrender some or all of the acreage to

19 Williams, 3 Oil \& Gas Law $\$ \$$ 604.7, 606.9, 628, 658 (1969).

so See, e.g., Gulf Oil Corp. v. Reid, 161 Tex. 51, 337 S.W. 2nd 267, 12 O. \& G.R. 1159 (1960), loss of lease because shut in gas royalty not immediately tendered for successful gas well completed after end of primary term; Rogers v. Oshorn, 152 Tex. 540, 261 S.W. 2d 311, 2 O. \& G.R. 304, 1439 (1953), loss of lease after successful drilling because Thirty Day-Sixty Day Clause failed to cover precise fact situation; Superior Oil Co. v. Stanolind Oil \& Gas Co.. 150 Tex. 317, 240 S.W. $2 d$ 281 (1951), lessee loses lease through misinterpretation of dry hole clause after completion of successful producer; Watson v. Rochmill, 137 Tex. 565. 155 S.W. 2d 783 (1941), cessation of production in secondary term during the Depression, estoppel argument rejected; Stanolind Oil \& Gas Co. v. Barnhill, 107 S.W. 2d 746 (Tex. Civ. App. 1937, error refd) discovery of gas does not satisfy Habendum Clause without production and marketing; Young v. Jones, 222 S.W. 691 (Tex. Civ. App. 1920) underpayment of $\$ 2.96$ of delay rental.

21 Compare Rogers v. Osborn, 152 Tex. 540, 261 S.W. 2d 311, 2 O. \& G.R. 304, 1439 (1953) with Stanolind Oil \& Gas Co. v. Newman Bros. Drilling Co., 157 Tex. 489, 305 S.W. 2d 169, 7 O. \& G.R. 1496 (1957) further, compare Gulf Oil Corp. v. Reid, 161 Tex. 51, 337 S.W. 2d 267, 12 O. \& G.R. 1159 (1960) with Skelly Oil Co. v. Harris, 163 Tex. 92, 352 S.W. 2d 950, 15 O. \& G.R. 653 (1962). 
avoid the payment obligation. Such a contract might specify that the property interest created is an irrevocable license for the term of the agreement, but that its terms are to be construed as an ordinary undertaking with substantial performance satisfying the contractual obligations and with termination of the contract depending on a substantial breach of a material provision. So far as I know this has not been attempted, and perhaps it is much too late in the day to try it. Nevertheless, whatever the unknown risks of such an agreement may be, I find it hard to believe that those risks are graver than the known risks of the present form of oil and gas lease.

\section{G. TITLE REGISTRATION}

The two papers on title registration problems of oil and gas interests come as something of a shock to an American law teacher without experience in the Torrens title registration system. It is conventional learning in the United States that the Torrens title registration system is far superior to our land records system, and I suspect that proposition remains true for ordinary transfers of farms and residences in fee simple absolute. The difficulty seems to arise when sophisticated interests such as carved-out oil payments, overriding royalty interests, net profits interests, and even farmouts are created in the minerals. With very little knowledge of the actual operation of the title registration system in Saskatchewan and Alberta, this commentator hesitates to perform his commenting function fully, but at the same time he cannot help wondering whether the defect is in the legislation or in the administration of the system. It is my view that the great variety of interests created in oil and gas properties in the United States has served a useful social function in permitting flexible financing of oil and gas ventures, and in providing an assortment of investment opportunities. For the title registration system to inhibit this flexibility, because the system is not adapted to oil and gas transactions, seems unfortunate. Meanwhile, of course, Canadian oil and gas lawyers must live with the system, and the papers by $\mathrm{Mr}$. Schmidt $^{22}$ and Mr. Bonney ${ }^{23}$ represent careful analyses of the problems presented and of possible avenues of escape from the dangers of the present system.

22 Schimidt, Title Problems Concerning Unregistered and Unregistrable Interests in Oil and Gas Properties, infra, at 559.

2 Bonney, id., at 559 and 569. 